UDK 811.163.42’374:316.647.8

Izvorni znanstveni rad Rukopis primljen 25. III. 2021. Prihvaćen za tisak 21. V. 2021. doi.org/10.31724/rihjj.47.2.11

\author{
Ana Perinić Lewis \\ Institut za antropologiju \\ Ulica Ljudevita Gaja 32, HR-10000 Zagreb \\ orcid.org/0000-0002-2425-1061 \\ aperinic@inantro.hr \\ Kristian Lewis \\ Institut za hrvatski jezik i jezikoslovlje \\ Ulica Republike Austrije 16, HR-10000 Zagreb \\ orcid.org/0000-0002-9202-9702 \\ klewis@ihjj.hr
}

\title{
STEREOTIPNI NAZIVI ZA OTOČANE TE STANOVNIKE PRIOBALJA I NJEGOVA ZALEĐA U RJEČNICIMA HRVATSKOGA JEZIKA
}

U radu ${ }^{1}$ se razmatraju stereotipni nazivi bodul, školjar i vlah. Analizira se u kojim im se značenjima i kontekstima pripisuju stereotipne značajke te se donose etimološka tumačenja. Značenja, uporabni kontekst i terminološka neujednačenost provjeravaju se u standardnojezičnim i dijalektnim rječnicima hrvatskoga jezika. Prikazuje se rasprostranjenost navedenih naziva duž Jadrana i nude se zaključci o tome je li riječ o regionalnoj ili nadregionalnoj pojavi.

\section{Uvod}

U ovome radu istražuju se stereotipni nazivi za otočane i stanovnike priobalnoga zaleđa, a temelj istraživanja čini analiza triju naziva - bodul, školjar i vlah - u rječnicima hrvatskoga jezika. U prethodnim istraživanjima razmatranoga fenomena uočena je višeznačnost naziva i uporabna raznolikost, često ovisna o

\footnotetext{
1 Rad je napisan u okviru projekta Hrvatski mrežni rječnik-MREŽNIK(IP-2016-06-2141), koji u potpunosti financira Hrvatska zaklada za znanost.
} 
području na kojemu se naziv upotrebljava ili o području s kojega autor potječe. Navedeni nazivi, dakle, u većini slučajeva nemaju neutralno značenje. Upravo suprotno, često zbog generalizacija, pojednostavnjivanja i stereotipiziranja te činjenice da se mogu bez problema primijeniti na različite skupine stanovnika imaju odlike stereotipa. U znanstvenim radovima o navedenim nazivima vidljiva je terminološka (naziv, ime, etnonim, etnik, apelativ) ${ }^{2}$ i pravopisna raznolikost (pisanje naziva malim ili velikim početnim slovom) ${ }^{3}$, što također svjedoči o određenoj fluidnosti pojmova i nesigurnosti autora o tome kako ih zapisati i definirati.

Metodološki smo istraživanje proveli u tri faze. U prvoj smo fazi pretražili i ispisali pojavnice naziva u općejezičnim rječnicima hrvatskoga jezika (dvama normativnim rječnicima, jednome deskriptivnome i jednome rječniku stranih riječi) i u dijalektnim (mjesnim, ali i otočnim) rječnicima hrvatskoga jezika, njih dvadeset. Općejezične rječnike uključili smo kako bismo ponajprije provjerili pojavljuju li se nazivi bodul, školjar i vlah u kontekstu koji hrvatski standardni jezik podrazumijeva (naddijalektni, općeuporabni karakter) te postoje li stereotipne predodžbe u definicijama u tim rječnicima. Dijalektne rječnike uključili smo u istraživanje jer smo pretpostavili da će se u tim rječnicima pojaviti istraživani nazivi te da ćemo iz potvrda u njima moći donijeti zaključke o prvotnoj i povratnoj stereotipizaciji (kopno - otok, odnosno tko je stanovnicima kopna bodul i/ili školjar; zatim otok - kopno, odnosno tko je otočanima vlah; i na kraju otok - otok, odnosno postoje li stereotipi među samim otočanima - unutarotočne i međuotočne stereotipizacije). Kako bi se utvrdili i dodatno provjerili svi ovi odnosi, na mjestima na kojima je to bilo moguće uveli smo i tzv. kontrolne rječnike, to jest rječnike kopnenih govora koji su smješteni na područjima nasuprot otocima, njih sedam. Tijekom istraživanja bilježili smo značenja, definicije i uporabni kontekst ilustriran rečeničnim primjerima kako bismo njihovom ana-

\footnotetext{
2 Stereotipnim nazivom ili samo nazivom u ovome ćemo radu imenovati analizirane rječničke natuknice jer s terminološkoga gledišta (stereotipni) naziv ima najširi pojmovni opseg. Pri izravnome navođenju drugih autora koristit ćemo se njihovim terminološkim odabirom.

3 Iako supostoji mnoštvo dijalektnih likova, a zatim i pravopisno neusustavljenih zapisa s obzirom na upotrebu velikoga i maloga početnog slova, odlučili smo u autorskome tekstu upotrebljavati likove bodul, školjar i vlah kao neutralne odnosno kanonske likove. Učinili smo to jer, kako će pokazati provedena analiza, zapis malim početnim slovom pretežno sadržava stereotipno značenje i uglavnom je apelativ, a zapis poput Bodul, Školjar i Vlah odnosi se na konkretne stanovnike kojega područja ili se upotrebljava kao etnonim. U navodima drugih autora potvrde se donose u izvornome zapisu bez ikakve prilagodbe (fonološke, grafijske, naglasne i dr.).
} 
lizom potkrijepili stereotipne kontekste u kojima se nazivi bodul, školjar i vlah pojavljuju.

U drugoj smo fazi rezultate razvrstali s obzirom na geografski prostor na kojemu su nazivi zabilježeni (kvarnerski otoci i otok Pag, sjevernodalmatinski otoci, srednjodalmatinski i južnodalmatinski otoci) te proveli značenjsku analizu. U trećoj smo fazi iznijeli zaključke o tome je li riječ o regionalnoj ili nadregionalnoj pojavi.

\section{Stereotipi i stereotipiziranje među društvenim skupinama}

Istraživanja stereotipa su interdisciplinarna i transdisciplinarna tema (Kolbas 2013: 10-11). Bez obzira na različite pristupe i disciplinarne okvire, većina istraživača jednomu stereotipu pripisuje pojednostavnjeno i uopćeno prikazivanje pojava i kolektiva. U kulturnim istraživanjima pojam stereotipa odnosio se „na uvriježene slike i predodžbe koje skupine imaju jedna o drugoj" (Čapo Žmegač 2002: 24). Stereotip se promatra kao predodžba, skup ili sustav predodžba, koje dijele pripadnici jedne društvene skupine o zajedničkim karakteristikama pripadnika svoje ili bilo koje druge skupine ljudi. Stereotipe kao „slike u glavama" određuje i njihov tvorac, novinar i komentator Walter Lippmann, koji je taj termin upotrijebio u svojoj knjizi Public Opinion (u hrvatskome prijevodu iz 1995. Javno mnijenje), objavljenoj u New Yorku 1922. godine. Slike ili predodžbe oblikuju se na temelju kulturnih utjecaja i svakodnevnih iskustava iz okruženja u kojemu živimo (Lippmann 1995: 25). Lippmann je smatrao da se stereotipi o okolnom svijetu, ljudima, zemljama i raznim pojavama prenose kao oblik kulturnog znanja ili baštine s jedne generacije na drugu, ,mi izaberemo ono što je naša kultura za nas već definirala” (Lippmann 1995: 66). Stereotipi se mogu shvatiti kao „neka vrsta sedimentiranog, tj. utvrđenog znanja što ga već posjedujemo i često uopće više ne znamo točno odakle" (Fehér 2006: 60).

Prema Peteru L. Bergeru i Thomasu Luckmannu (1992: 40) zbilja je određena kao socijalna konstrukcija, a jezik se smatra najvažnijim sustavom ljudskoga društva, ključnim za razumijevanje zbilje: „Jezik objektivira zajednička iskustva i čini ih raspoloživima za sve unutar jezične zajednice, postajući tako i osnova i sredstvo kolektivne zalihe znanja" (Berger i Luckmann 1992: 89). Ta 
zaliha znanja pojedincu nudi tipizirane sheme ili stereotipe koji mu pojednostavnjuju kompleksnu društvenu zbilju i njezine sudionike. Pojam kategorije često se preklapa s pojmom stereotipa, stereotipi su neka vrsta „okamenjenih kategorija" (Pickering 2001: 29), a stereotipizacija bi u tom smislu bila oblik društvene kategorizacije prema kojoj se svim članovima jedne kategorije pripisuje posjedovanje istih značajki, a svakom pojedincu koji se percipira kao pripadnik te kategorije pripisuje se posjedovanje tih značajki. Hrvoja Heffer (2007: 170) razlikuje stereotipizaciju i stereotipiziranje. Stereotipizacijom se smatra proces nastanka stereotipa kroz jezično-društvene okolnosti i praksu, a stereotipiziranje je praktična primjena udomaćenih stereotipa u komunikacijskoj praksi. Stereotipiziranje kao interakcija govornika i slušatelja ima tri dimenzije: jezična ili leksička pojavnost, društvene okolnosti u kojima nastaju stereotipi i u kojima ih se primjenjuje te psihološko motrište i stanje koje obuhvaća reakciju govornika koji odabire stereotip i koristi se njime u određenoj govornoj situaciji te onoga koji ga prima (Heffer 2007: 170). Zavodljivost je stereotipa u njihovoj sposobnosti pojednostavnjenja složenoga i nesvodivoga u jednostavno i razumljivo.

Postoje različite vrste stereotipa, no najčešći su oni koje se odnose na drugoga, pojedinca ili zajednicu. Što nam je drugi bliži, potreba je za razgraničavanjem snažnija i stvaranje stereotipnih predodžba postaje intenzivnije. Blizina drugoga izvor je stereotipizacija. Stereotipi mogu biti negativni i pozitivni, ovisno o tipu odnosa među skupinama. Najčešće se susreću negativne stereotipizacije, koje katkad znaju prijeći i u predrasude ili čak stigme, a obično su povezane sa stvarnom ili umišljenom opasnošću zbog blizine drugosti. Stereotipi reduciraju kompleksnost pa je proces stereotipiziranja binaran i dihotoman. Prema Stuartu Hallu, dva su aspekta stereotipiziranja: prvi se povezuje s konstrukcijom drugosti i isključivanjem, a drugi aspekt povezuje stereotipiziranje i moć. Stereotipiziranje ,umanjuje, svodi na nepromjenjivu bit, udomaćuje i utvrđuje različitost” (Hall 1997: 258). Moć je drugi važan aspekt stereotipiziranja jer se pojavljuje ondje gdje postoje nejednakosti u moći, a usmjerena je protiv podređenih ili isključenih skupina. Pierre Bourdieu navodi kako „samo oni koji raspolažu legitimnim autoritetom proizašlim iz moći mogu nametnuti vlastite definicije o sebi i drugima. Sklop identitetskih definicija funkcionira kao sustav 'klasiranja' koji ustanovljuje odgovarajuće pozicije svake grupe" (Bourdieu 1991: 239-240). Stereotipi nisu ni istiniti, ni lažni jer se mogu ,,primijeniti sad na jednu, sad na drugu skupinu da bi se stigmatizirala" (Čapo Žmegač 1997: 72). Istinitost stereotipa 
ne može se empirijski dokazati, stoga ga je potrebno stalno ,ponavljati u promjenjivim povijesnim i diskurzivnim sklopovima” (Bhabha 1994: 77). Stereotipne predodžbe tim umnažanjem istoga nastaju i traju tijekom duljih razdoblja, često zahvaćaju nekoliko stoljeća, vremenski su postojane. Stereotipi su ,fenomeni dugog trajanja" (Džambo 1999: 118), ali se ipak s vremenom modificiraju ili katkad posve mijenjaju.

\section{Općenito o nazivima vlah, bodul i školjar}

\subsection{Naziv vlah}

Najstarija i najdugovječnija opreka otočnoga i kopnenoga stanovništva očuvana je u nazivima vlah i bodul. Podvojenost stanovnika uz more i gorštaka karakteristična je za cijeli sredozemni prostor (Braudel 1997, Matvejević 2006). Oba naziva susreću se u povijesnim izvorima od 14. do 18. stoljeća (Mirdita 2004, Botica 2005). Petar Skok (1973: 606-609) prvi donosi pregled značenja naziva Vlah. Tumačenja naziva grupiraju se u dva značenjska pola: ,samosvojni etnoidentitet” i ,pokazatelj kohabitacije sociokulturnih različitosti među stanovništvom” (Botica 2007: 63). August Kovačec također ističe višeznačnost naziva pod kojim su se u različitim razdobljima i u različitim sredinama podrazumijevale različite etničke, društvene, profesionalne, vjerske i druge skupine (Kovačec 2016: 3). Ivan Botica navodi četiri novije odrednice naziva Vlah: 1. vjerska (Vlasima su se obilježavali pripadnici konfesionalno različitih naroda na integrativno labavome teritoriju), 2. dijalektna (odrednica se tiče statusa naziva u neštokavskim dijalektima), 3. geografska (na srednjodalmatinskome području naziv označuje stanovnika kontinentalne Dalmacije, a među otočanima Vlasima se nazivaju oni iz unutrašnjosti otoka) i 4. socijalna odrednica (Vlah je nekad bio stočar, pastir, a u novije doba seljak iz dalmatinskog zaleđa) (Botica 2007: 65). Kovačec (2016: 8) ističe da se etnička i jezična distinkcija u Dalmaciji i na otocima odavno izgubila te da se očuvala ,distinkcija socijalnoga tipa”, koja je osobito zanimljiva za istraživanje stereotipa. Već Skok (1973: 606, s. v. Vlah) uz navedeno značenje 'seljak iz unutrašnjosti' donosi i značenje 'osoba nekonvencionalnih ili pak neuljuđenih manira'. Botica (2007: 65) ističe da naziv vlaj na srednjodalmatin- 
skome, odnosno širemu splitskom području ima pejorativna značenja ,seljak, neuk, kulturno inferioran (primitivac), sirov".

U radovima o ovoj temi nerijetko su posebno istaknuti otočani i njihova specifična upotreba naziva vlah. ${ }^{4}$ Dok se taj naziv na kopnu upotrebljava za stanovnike kontinentalne unutrašnjosti, na otocima je to najčešći naziv za neotočanina. Prije svega za svakoga stanovnika kopna, bez obzira na to živi li u primorju ili planinskome zaleđu, a onda i za stanovnike za koje se zna da su se na otok doselili u prošlosti. U drugome se značenju ovaj naziv odnosi na ljude koji se ne razumiju u more i brodove. Tako se opreka kopno - otok preslikava i u unutarotočnim podjelama.

\subsection{Naziv bodul}

Opreka je nazivu vlah naziv bodul, koji su stanovnici kopna nadijevali otočanima. ${ }^{5}$ Etimologija naziva višeznačna je. Pojavljuju se tumačenja naziva izvedena iz mletačkog pridjeva bodolo, koji se najprije odnosio na niskoga, odebljega muškarca ili ženu, a zatim se upotrebljavao i za vojnika pješaka u službi Venecije. Deminutiv bodoleto označuje maloga bijesnog psa (Skok 1971: 178, s. v. Boduo). Mate Suić usustavljuje prethodne spoznaje o etimologiji naziva te postavlja tezu da je naziv bodul ,autohtonog” postanja i da potječe iz vremena prije mletačke vladavine, izvodeći ga iz lat. vadum, množina vada (gaz, pličina, a poslije i ljudi ograničene, 'plitke' pameti). Smatra da se prvi put pojavio ,na najužem području romanskog grada Krka i oko njega (u izvornoj 'boduliji')" (Suić 1989: 23-24). Navodimo i dvije pučke etimologije, koje smatramo korisnima jer iznose

\footnotetext{
4 Skok (1973: 607) već navodi da „stanovnike Maslinice na Šolti (katolici) zovu ostali Boduli Vlasima. Jednako tako zovu Hvarani stanovnike Sućurja, a Bračani stanovnike Sumartina”. Maslinica, Sućuraj i Sumartin naseljeni su uglavnom stanovništvom iz priobalja za mletačko-osmanskih ratova u 17. stoljeću. Čakavsko ih starosjedilačko stanovništvo zbog toga i naziva Vlasima. Novija istraživanja pokazuju da su pojedini spomenuti govori danas čakavizirani poput govora Maslinice na Šolti (Galović 2019: 43). Kovačec također ističe da se „na otocima naziv Vlah, Vlasi upotrebljava za stanovnike za koje se zna da su se na određeni otok doselili tijekom proteklih stoljeća (...) bez ikakve aluzije na kakvu posebnu etničku ili lingvističku pripadnost i za sezonske radnike koji su na otoke dolazili iz Dalmatinske zagore" (Kovačec 2016: 8).

5 Ivan Botica uočava rano postojanje suodnosa između naziva Bodul i Vlah te ih imenuje 'obostranim nadimcima': „To su područja [tj. mediteransko/submediteransko primorje i dinarsko-krški planinski prostor] različitih gospodarskih i kulturnih krajolika koja su sklona, sasvim razumljivo, svakojakim obostranim nadimcima." (Botica 2005: 41).
} 
bitne izvanjezične podatke, ali smo svjesni da etimološki nisu relevantne. Prvu takvu pučku etimologiju donosi Ivan Lovrić u 18. stoljeću, izvodeći naziv iz glagola bosti, ,odgovara talijanskome: pugnono essi? (bodu li?)” (Lovrić 1948: 60). Među recentnijim raspravama o (pučkoj) etimologiji naziva bodul nalazimo rad Antona Bozanića, koji donosi pregled članaka objavljenih u Krčkome kalendaru o toj temi (2019). Tako navodi da u Krčkome kalendaru za 1954. (izašao u New Yorku te godine) u članku Otkuda i što znači riječ Bodul nepotpisani autor (Bozanić ga atribuira uredniku Kalendara Nikoli Fabijaniću) objašnjava da značenje naziva Bodul dolazi od stare hrvatske, odnosno „hrvatskoslavenske” riječi dol s prijedlogom $v$ i glasi v' doli ili b' doli, a ,odnosi se na one koji žive dolje”. Za ljude ispod Velebita oni koji žive dolje su boduli, a za otočane (Krčane) ljudi s kopna su oni koji žive gore i nazivaju ih gorinci (Bozanić 2019: 151).

Već pri izvođenju etimologija naziva bodul vidljiva su pretežno negativna i pogrdna značenja te se može kazati da je uspostavljen kao opreka drugoj skupini (Mlečani - Slaveni, stanovnici kopna - otočani, ali i stanovnici jednoga otoka stanovnici drugoga otoka). Tako Skok navodi da je Boduo ,etnik koji stanovnicima na kopnu označuje otočane u Kvarneru, Bračane i Hvarane, a nazivom Bodulac naziva narod Sinjske krajine i Zagorja otočane i primorce srednje Dalmacije u podrugljivom značenju" (Skok 1971: 178). Na navedenome mjestu uparuje ga s nazivima Vlah i Kranjac uz tumačenje da sva tri imaju pejorativno značenje. Nadalje, i Suić zagovara mišljenje ,da naziv 'vlaj' prema nazivu 'bodul' stoji u približno jednakovrijednoj semantičkoj opoziciji; ovamo vlaško lukavstvo (furbarija) u shvaćanju otočana i primoraca (usp. izraz na tal.: furbo morlaco) onamo boduli, kojima upravo nedostaje ta osobina, koji znaju biti dobroćudni, lakovjerni, pa i naivni te će u sporu s vlahom često izvući tanji kraj” (Suić 1989: 26).

Kad je riječ o rasprostranjenosti naziva bodul, vidljivo je da je naziv nastao na području Kvarnera, gdje se najviše upotrebljava (i to za Krčane), a otočani ga uglavnom prihvaćaju. Izgledno je da se odande širio na druge otoke i počeo odnositi na druge otočane, sve do srednjodalmatinskih i južnodalmatinskih otoka, gdje većina izvora navodi kako do novijega vremena nije bio ni poznat, ni prihvaćen (usp. Novak 1959: 73, Suić 1989: 23). Međutim, zanimljivo je da Bozanić navodi kako je u članku Nešto o Bodulima i bodulariji, objavljenome 1952. godine u Krčkome kalendaru, književnik i pravnik Antun Nizeteo ustvrdio da ,svaki naš grad na moru koji ima pred sobom otok, posebice u sjevernom 
i srednjem Jadranu, ima svoje bodule. Za Zadrane su to mještani Pašmana i Ugljana, za Splićane ponajprije Bračani, a manje Šoltani, za Trogir stanovnici Čiova, a za Riječane i ljude s obale Kvarnera boduli su Krčani, ali također Cresani, Lošinjani, Rabljani i Pažani” (Bozanić 2019: 147). Time se postavlja teza da se naziv bodul upotrebljava za stanovnike otoka koji je najbliži kopnu, što će se potvrditi i analizom potvrda naziva bodul u dijalektnim rječnicima hrvatskoga jezika.

\subsection{Naziv školjar}

Naziv školjar također se odnosi na otočanina. Etimologija naziva jednostavnija je i izvodi se iz mletačkoga scogio > scoglio $>$ škojo u značenju mali otok, otočić. Dodavanjem sufiksa -ar tvori se školjar (škojor) 'otočanin' (Skok 1973: 273, s. v. Skupio). Iako u skromnoj sekundarnoj literaturi nema potvrda o podrugljivim značenjima kao kod naziva bodul, postoje naznake da se koristi i kao stereotipno ime, ali u međuotočnim stereotipizacijama. Skok na citiranome mjestu navodi da škojorima Bračani zovu stanovnike otoka Hvara. Naša analiza pokazat će još sličnih primjera.

\section{Nazivi bodul, školjar i vlah u rječnicima}

\subsection{Nazivi bodul, školjar i vlah u općejezičnim rječnicima hrvatskoga jezika}

Spomenuta tri naziva potražili smo i analizirali njihova značenja, navedena u definicijama i primjerima uporabe u rečeničnome kontekstu, u općejezičnim rječnicima hrvatskoga jezika ${ }^{6}$ - normativnome Rječniku hrvatskoga jezika glavnoga urednika Jure Šonje i Velikome rječniku hrvatskoga jezika glavne urednice Ljiljane Jojić, deskriptivnome Velikome rječniku hrvatskoga jezika Vladimira Anića te u Novome rječniku stranih riječi Bratoljuba Klaića i Školske knjige. U

\footnotetext{
6 Ivan Botica u dvama je općejezičnim rječnicima (Anićevu i Šonjinu) provjerio pisanje i značenja naziva Vlah/vlah te zaključio da razlika u pisanju velikoga i maloga početnog slova podrazumijeva i značenjsku razliku. (Botica 2007: 62)
} 
svim se analiziranim rječnicima pojavljuju nazivi bodul i vlah, a naziv školjar nalazimo samo u Šonje i u VRH-u. Uz opća značenja navedena su i pejorativna i derogativna značenja, uglavnom uz naziv vlah, koji dolazi u najvećemu broju inačica, odnosno kao pogrdna uvećanica vlašina samo u Šonje (2000: 1361).

Tablica 1. Potvrde naziva bodul, školjar i vlah u općejezičnim rječnicima hrvatskoga jezika

\begin{tabular}{|l|l|l|l|}
\hline VRHJ (Anić 2005) & RHJ (Šonje 2000) & VRH (Jojić 2015) & NRSR (Klaić 2012) \\
\hline $\begin{array}{l}\text { bodul (bodulica, } \\
\text { Bodul) }\end{array}$ & $\begin{array}{l}\text { Bodul (Bodulka, } \\
\text { bodul) }\end{array}$ & $\begin{array}{l}\text { bodul } \\
\text { bodulica } \\
\text { bodulka }\end{array}$ & $\begin{array}{l}\text { bodul (bodulica, } \\
\text { bodulka) }\end{array}$ \\
\hline $\begin{array}{l}\text { Vlah (Vlahinja, } \\
\text { vlah) } \\
\text { vlaj (vlajina) }\end{array}$ & Vlasi (vlasi) & $\begin{array}{l}\text { vlaj (Vlaj) } \\
\text { vlajinja (Vlajinja) }\end{array}$ & Vlah (Vlaj) \\
\hline- & Vlasi (vlasi) & $\begin{array}{l}\text { školjar } \\
\text { školjarica }\end{array}$ \\
\hline
\end{tabular}

* U tablici se navode natuknice kako su donesene u pojedinome rječniku, a u zagradama se donose podnatuknice i njihova dodatna značenja ako ih ima.

U Anićevu i Šonjinu rječniku nalazimo dvostruke zapise naziva bodul, pri čemu se zapis koji počinje malim početnim slovom u obama rječnicima određuje značenjem 'otočanin', a zapis koji počinje velikim početnim slovom (Bodul) - 'Krčanin, stanovnik Krka'. Anić prvo značenje obilježava kao regionalno i pejorativno, a Šonje kao preneseno. U VRH-u i u Klaića natuknica je pisana samo malim početnim slovom, a odrednice su regionalno i razgovorno (VRH), dok u Klaića nema odrednice.

Najveći je broj inačica zapisa naziva vlah. Anić i Klaić uspostavljaju natuknicu pisanu velikim početnim slovom u jednini (Vlah), a Šonje i VRH donose natuknicu u množini (Vlasi). U svim se slučajevima takav zapis definira kao etnonim. Zapis malim početnim slovom (vlah, vlasi) obuhvaća značenja 'pravoslavac (za katolike i muslimane)' i 'u Istri došljak (za razliku od starosjedilaca)' (Anić 
2005: 1746), nadalje 'brdski pastir, stočar' i 'stanovnik primorskog zaleđa za primorce' (Šonje 2000: 1360), dok u VRH-u nalazimo sva prethodno navedena značenja (Jojić 2015: 1692). Inačicu vlaj kao zasebnu natuknicu donose Anić i VRH, a Klaić je objašnjava u sklopu leksikografske definicije natuknice Vlah. Nije potvrđena samo u Šonjinu rječniku. U Anića i u VRH-u pisana je malim početnim slovom, a u Klaića velikim. Značenja su istovjetna u Anića i u VRH-u: 'stanovnik zaleđa (za stanovnike primorja i otoka), Morlak', 'stanovnik zaleđa i obale (za stanovnike otoka)' i u pejorativnom značenju 'seljak, seljačina' (Anić 2005: 1746, Jojić 2015: 1692). Klaić definira naziv Vlaj pod natuknicom Vlah: 'naziv Vlaj daju i danas stanovnici naših primorskih krajeva seljacima iz svoga kontinentalnog zaleđa (bez obzira na vjersku pripadnost)' (Klaić 2012: 1117).

Na kraju, samo u Šonje i u VRH-u nalazimo natuknicu školjar, definiranu jednako: 'stanovnik školja' (Šonje 2000: 1223, Jojić 2015: 1520).

\subsection{Nazivi bodul, školjar i vlah u dijalektnim rječnicima hrvatskoga jezika}

Nazive bodul, školjar i vlah i njihove inačice istražili smo i analizirali u dostupnim dijalektnim rječnicima cijelih otoka ili pojedinih otočnih mjesta. Istraživanje je obuhvatilo 20 rječnika s 14 otoka iz četiriju otočnih skupina: kvarnerske, sjevernodalmatinske, srednjodalmatinske i južnodalmatinske. Otoke smo podijelili prema uobičajenoj geografskoj podjeli na pet otočnih skupina ${ }^{7}$ (Rubić 1952, Stražičić 1987). Kako smo već napomenuli, u istraživanje smo uključili i tzv. kontrolne rječnike kako bismo dodatno provjerili značenja razmatranih naziva. Riječ je o rječnicima kopnenih govora s područja nasuprot otocima. Takvih je rječnika sedam, tri su kontrolna za skupinu dijalektnih rječnika kvarnerskih otoka, dva za skupinu dijalektnih rječnika sjevernodalmatinskih otoka i dva za skupinu dijalektnih rječnika srednjodalmatinskih i južnodalmatinskih otoka.

Ovim istraživanjem nisu obuhvaćeni otoci zapadnoistarske otočne skupine. 


\subsection{Nazivi bodul, školjar i vlah u dijalektnim rječnicima kvarnerskih otoka i otoka Paga}

Istražili smo dva rječnika mjesnih govora otoka Krka (Omišalj, Čižići) i rječnik Bejske Tramuntane na otoku Cresu. Otok Pag priključili smo ovoj skupini kao otok na granici Primorja i Dalmacije te jedini hrvatski otok podijeljen između dviju županija (sjeverni dio otoka - Grad Novalja - pripada Ličko-senjskoj, a južni - Grad Pag, Općina Kolan i Općina Povljana - Zadarskoj županiji) (Mirošević i Vukosav 2010). Otoka Pag zastupljen je s četirima rječnicima mjesnih govora: grada Paga, Novalje, Kolana i Povljane.

Tablica 2. Potvrde naziva bodul, školjar i vlah u dijalektnim rječnicima kvarnerskih otoka i otoka Paga

\begin{tabular}{|c|c|c|c|c|c|c|}
\hline $\begin{array}{l}\text { Omišalj } \\
\text { (o. Krk) } \\
\text { (Mahulja } \\
\text { 2006) }\end{array}$ & \begin{tabular}{|l} 
Čižići/ \\
Dobrinj \\
(o. Krk) \\
(Turčić \\
2002)
\end{tabular} & \begin{tabular}{|l|} 
Bejska \\
Tramuntana \\
(o. Cres) \\
(Velčić 2003)
\end{tabular} & $\begin{array}{l}\text { Novalja } \\
\text { (o. Pag) } \\
\text { (Vranić i } \\
\text { Oštarić } \\
\text { 2016) }\end{array}$ & $\begin{array}{l}\text { Grad Pag } \\
\text { (Kustić } \\
\text { 2002) }\end{array}$ & \begin{tabular}{|l} 
Kolan \\
(o. Pag) \\
(Oštarić \\
2005)
\end{tabular} & \begin{tabular}{|l} 
Povljana \\
(o. Pag) \\
(Tičić 2004)
\end{tabular} \\
\hline $\begin{array}{l}\text { Bôdul } \\
\text { Bodulïja }\end{array}$ & - & \begin{tabular}{|l|} 
Bôdul \\
Bodulïja
\end{tabular} & $\begin{array}{l}\text { bôdul } \\
\text { bôdulka }\end{array}$ & - & Bödul & \begin{tabular}{|l} 
bôdul \\
bodulìca \\
bodulìna \\
\end{tabular} \\
\hline- & - & - & \begin{tabular}{|l} 
Vläh \\
Vlaharïja \\
Vlähinja
\end{tabular} & $\begin{array}{l}\text { vläh } \\
\text { vlähinja } \\
\text { vlaharîja }\end{array}$ & \begin{tabular}{|l} 
Vläh \\
Vlähinja \\
Vlaharïja
\end{tabular} & \begin{tabular}{|l} 
Vläj \\
Vläjina \\
Vläsi \\
Vlaharïja
\end{tabular} \\
\hline- & škojân & śkojân & - & $\begin{array}{l}\text { śköjar } \\
\text { śköjarka }\end{array}$ & šköljar & - \\
\hline
\end{tabular}

Na kvarnerskim otocima Krku i Cresu pojavljuju se naziv bodul i ško(l)jar, ali u navedenim rječnicima nema naziva vlah. Bodul je na tim područjima prihvaćen kao naziv za otočanina. Iako je u prošlosti bio pejorativan, danas nije, osobito na otoku Krku. Mahulja (2006: 27) i Velčić (2003: 149) pišu ga velikim početnim slovom i određuju kao naziv za stanovnika otoka Krka. I naziv Bodulija opisuju kao otočni prostor na kojemu žive boduli, a sinonim je za otok Krk. U rječniku sela Čižića u općini 
Dobrinj ne nalazimo ni naziv bodul, ni naziv vlah, samo naziv škojan za otočanina (Turčić 2002: 237), koji je potvrđen i u rječniku Bejske Tramuntane na otoku Cresu (Velčić 2003: 460). ${ }^{8}$

Otok Pag istodobno je sjevernodalmatinski otok i otok Kvarnerskoga zaljeva. I danas je jedini hrvatski otok podijeljen između dviju županija, a zastupljen je s četiri rječnika mjesnih govora: Novalje, grada Paga, Kolana i Povljane. Naziva bodul nema samo u rječniku grada Paga, dok je naziv škojar potvrđen u Kolanu i gradu Pagu. U svim se paškim rječnicima nalazi naziv vlah u raznim inačicama, ali i značenjima. Nazivi Vlah i Vlahinja, pisani velikim početnim slovom, u Kolanu znače 'Ličanin' i 'Ličanka' (Oštarić 2005: 573), a u Novalji 'stanovnika i stanovnicu južnog podvelebitskog kraja i zaleđa’ (Vranić i Oštarić 2016: 736). Inačice Vlaj i Vlajina nalazimo u rječniku Povljane u značenju 'koji živi na kopnu, ne pri moru, u Dalmatinskoj zagori (Bukovici)', dok inačica u množini Vlasi ima značenje koje donosi precizno geografsko određenje 'ljudi iz Ravnih kotara' (Tičić 2004: 399). U rječniku grada Paga nazivi vlah i vlahinja pišu se malim početnim slovom, definirani su u prvome značenju kao „stanovnik podvelebitskog kraja i stočar iz zaleđa", a u drugome, pejorativnom značenju dana je definicija „seljačina, koji se ne ponaša uljuđeno” (Kustić 2002: 405). Naziv Vlaharija/vlaharija pojavljuje se u svim paškim rječnicima. U Povljani i Kolanu on ima prostorno određenje te se definira s ,prostor ili područje na kopnu, ne pri moru" (Tičić 2004: 399), a na primjeru iz Kolana „prostor preko Velebita” (Oštarić 2005: 573). U urbanim otočnim centrima Novalji i gradu Pagu Vlaharija/vlaharija definira se kao zbirna imenica za „stanovništvo južnog podvelebitskog kraja i zaleđa” (Vranić i Oštarić 2016: 736) ili, pisana malim početnim slovom, deprecijativno predstavlja „skupinu ljudi koji se ponašaju necivilizirano” (Kustić 2002: 405). U rječnicima grada Paga i mjesta Kolana pojavljuje se naziv školjar/ škojar i školjarka u značenju 'otočanin' i 'otočanka'.

\footnotetext{
8 Takvo poimanje zastupljeno je i u kontrolnim rječnicima. Nazivi Bodul 'Krčanin', Bodulija 'područje otoka Krka' i Bodulka 'Krčanka' potvrđeni su u crikveničkome rječniku (Ivančić Dusper i Bašić 2013: 58). Ondje je navedena i natuknica Školj sa značenjem 'otok Krk' (Ivančić Dusper i Bašić 2013: 232), ali naziva školjar ne nalazimo. U rječniku Ivanke Bralić, koji obuhvaća leksik Šmrike i Kraljevice, jednako su definirane natuknice Bodul 'Krčanin' i Bodulka 'Krčanka' (Bralić 2014: 21), a u grobničkome se rječniku osim značenja ‘Krčanin' i ‘Krčanka' uz natuknice Bodul i Bodulka navode i prenesena značenja - ‘škrtac' i ‘škrta žena' (Lukežić i Zubčić 2007: 175), što potvrđuje stereotipizaciju navedenih naziva.
} 


\subsection{Nazivi bodul, školjar i vlah u dijalektnim rječnicima sjevernodalmatinskih otoka}

Nazive bodul, školjar i vlah analizirali smo u rječnicima sedam mjesnih govora sjevernodalmatinskih otoka. Svi ti rječnici, osim rječnika govora Ista, donose naziv vlah; bodul je potvrđen u trima rječnicima - rječniku Ošljaka, Sali na Dugome otoku i Kukljice na Ugljanu, dok je naziv školjar potvrđen u rječniku otoka Ista i Kukljice na Ugljanu.

Tablica 3. Potvrde naziva bodul, školjar i vlah u dijalektnim rječnicima sjevernodalmatinskih otoka

\begin{tabular}{|c|c|c|c|c|c|c|}
\hline $\begin{array}{l}\text { otok Ist } \\
\text { (Smoljan } \\
\text { 2013) }\end{array}$ & \begin{tabular}{|l} 
otok \\
Rivanj \\
(Radulić \\
2002)
\end{tabular} & $\begin{array}{l}\text { otok } \\
\text { Ošljak } \\
\text { (Valčić } \\
\text { 2012) }\end{array}$ & \begin{tabular}{|l|} 
Kukljica \\
(o. Ugljan) \\
(Maričić 2000)
\end{tabular} & $\begin{array}{l}\text { Sali } \\
\text { (Dugi otok) } \\
\text { (Piasevoli } \\
\text { 1993) }\end{array}$ & $\begin{array}{l}\text { otok } \\
\text { Vrgada } \\
\text { (Jurišić } \\
\text { 1973) }\end{array}$ & \begin{tabular}{|l} 
otok \\
Murter \\
(Juraga \\
2010)
\end{tabular} \\
\hline- & - & $\begin{array}{l}\text { boduljôšs } \\
\text { bodulïca } \\
\text { bodularïja }\end{array}$ & $\begin{array}{l}\text { bôdul } \\
\text { bodulïca } \\
\text { bodularïja }\end{array}$ & $\begin{array}{l}\text { bôdul } \\
\text { bôdulìca }\end{array}$ & - & - \\
\hline- & \begin{tabular}{|l|} 
Vläh \\
Vlähińa \\
Vlahựôrija
\end{tabular} & $\begin{array}{l}\text { Vlâh } \\
\text { Vlâhnja } \\
\text { Vlahuôrija }\end{array}$ & $\begin{array}{l}\text { Vläh } \\
\text { Vlähinja } \\
\text { Vlahôrija }\end{array}$ & $\begin{array}{l}\text { Vläh } \\
\text { Vläsi } \\
\text { Vlahôrija }\end{array}$ & $\begin{array}{l}\text { Vläh } \\
\text { Vlähińa } \\
\text { Vlahôrija }\end{array}$ & \begin{tabular}{|l} 
Vläh \\
Vlähinja \\
vläh \\
Vlahôrija \\
Vläsi
\end{tabular} \\
\hline śköljar & - & - & šköljạr & - & - & - \\
\hline
\end{tabular}

U rivanjskome rječniku i rječniku govora Ošljaka pod zasebnim se natuknicama Vlah i Vlahinja definiraju kao muškarac odnosno žena „,s kopnenoga dijela zadarskog kraja” (Radulić 2002: 330, Valčić 2012: 244). Rječnik govora otoka Vrgade naziv Vlah/Vlasi određuje kao „oni koji žive na kopnu, ne pri moru” (Jurišić 1973: 232). U rječniku govora Kukljice na otoku Ugljanu naziv Vlah/Vlasi, uz uobičajenu odrednicu za one „,koji žive na kopnu, ne pri moru”, ima i geografski specifično određenje ,u Kukljici čovjek iz Ravnih kotara" (Maričić 2000: 334). Tako je i u rječniku otoka Murtera u kojemu su nazivi Vlah i Vlahinja pisani velikim početnim slo- 
vom i određeni kao stanovnik i stanovnica „Ravnih kotara i Bukovice”, dok oblik naziva u množini (Vlasi) obuhvaća i prostor i stanovnike te je tako i definiran: ,prostor i stanovnici Ravnih kotara i Bukovice” (Juraga 2010: 283). Osobitost je murterskoga rječnika činjenica da donosi i natuknicu vlah, pisanu malim početnim slovom, s definicijom ,osoba za koju se ne zna ni tko je ni odakle je". Upravo se ovaj opis može navesti kao prototipni stereotip za svakoga stranca. U saljskome rječniku potvrđen je množinski oblik Vlasi, definiran kao „Kotarci” (Piasevoli 1993: 406), a jedninski oblik Vlah odnosi se na stanovnike ,neodređenoga područja iznad mora" - Vlahorije (Piasevoli 1993: 405). Naziv Vlahorija ponovno ima dvostruka značenja. Prostorno značenje nalazimo u rivanjskome rječniku „kopneni predjel” (Radulić 2002: 331), u kukljičkome ,predjel udaljen od mora" (Maričić 2000: 334) i u saljskome rječniku ,područje iznad mora" (Piasevoli 1993: 405). U rječniku Murtera naziv se odnosi samo na osobe - ,pogrdan naziv za stanovnike primorskog zaleđa” (Juraga 2010: 283). Oba prethodna značenja objedinjena su u definicijama Vlahorije u ošljačkome i vrgadskome rječniku: ,naziv za žitelje i područje u zaleđu Zadra” (Valčić 2012: 244) i ,Vlasi, Vlaška, predjel udaljen od mora” (Jurišić 1973: 232).

Naziv bodul potvrđen je u tom liku u kukljičkome i saljskome rječniku (Maričić 2000: 25, Piasevoli 1993: 39), a u ošljačkome nalazimo lik boduljoš (Valčić 2012: 21). Svi nazivi imaju značenje 'otočanin', a naziv bodularija sa značenjem 'otoci nastanjeni otočanima' potvrđen je u ošljačkome i kukljičkome rječniku (Valčić 2012: 21, Maričić 2000: 25). Naziv školjar, bez ikakve značenjske opreke prema nazivu bodul, pojavljuje se u rječnicima Ista i Kukljice u značenju 'otočanin, stanovnik otoka' (Smoljan 2015: 348, Maričić 2000: 292). ${ }^{9}$

\footnotetext{
9 Stanje u kontrolnim rječnicima ovoga područja pretežno potvrđuje rezultate istraživanja sjevernodalmatinskih otočnih rječnika. U Šimunićevu Rječniku bibinjskoga govora nalazimo sljedeće potvrde: boduja/bodul/bodulac (ž. bodulica) 'otočanin, stanovnik otoka' (Šimunić 2013: 151); bodularija 'otoci sa svojim žiteljima' (Šimunić 2013: 151); školjar (ž. školjarka) ‘čovjek rođen na otoku ili stanuje na otoku’ (Šimunić 2013: 683). Kad je riječ o nazivu vlah, u Šimunića je potvrđen lik vlajo (ž. vlajina, vlajinka) 'onaj koji živi ili je podrijetlom iz mjesta koja su udaljenija od mora, Kotarac' (Šimunić 2013: 778), a pod množinskom natuknicom vlasi navedena je definicija, žitelji naselja podalje od obale, ali i naziv za takvo područje, naseljeni prostor Ravnih kotara i Bukovice" (Šimunić 2013: 778). Dublje u kopnenome zaleđu, u benkovačkome kraju, potvrđeni su likovi bodulac i bodulj'ca sa značenjima 'otočanin' i 'otočanka' (Pavlović i Pavlović 2018: 47), dok su natuknice Vlaj i Vlajinja određene s 'Bukovčanac' odnosno 'Bukovčanka' (Pavlović i Pavlović 2018: 566) s uputnicom na natuknicu Vlaji. Ta se pak natuknica definira kao „naziv koji se kroz pojedina povijesna razdoblja i u određenim društvenim sredinama odnosio na različite etničke (regionalne, socijalne
} 


\subsection{Nazivi bodul, školjar i vlah u dijalektnim rječnicima srednjodalmatinskih i južnodalmatinskih otoka}

Analizom sedam rječnika - pet srednjodalmatinskih mjesnih govora i dvaju južnodalmatinskih - dobivene su potvrde svih razmatranih naziva. Međutim, naziv bodul navodi se u četirima rječnicima, dok su nazivi školjar i vlah zastupljeni u svim rječnicima, osim šoltanskoga, te imaju višestruke inačice i značenja.

Tablica 4. Potvrde naziva bodul, školjar i vlah u dijalektnim rječnicima srednjodalmatinskih i južnodalmatinskih otoka

\begin{tabular}{|c|c|c|c|c|c|c|}
\hline $\begin{array}{l}\text { otok } \\
\text { Šolta } \\
\text { (Galović } \\
\text { 2019) }\end{array}$ & $\begin{array}{l}\text { Hvar } \\
\text { (o. Hvar) } \\
\text { (Benčić 2013) }\end{array}$ & $\begin{array}{l}\text { Pitve i } \\
\text { Zavala } \\
\text { (o. Hvar) } \\
\text { (Barbić } \\
\text { 2012) }\end{array}$ & $\begin{array}{l}\text { otok Brač } \\
\text { (Šimuno- } \\
\text { vić 2009) }\end{array}$ & $\begin{array}{l}\text { Vis (o. Vis) } \\
\text { (Roki- } \\
\text {-Fortunato } \\
1997 \text { ) }\end{array}$ & $\begin{array}{l}\text { Korčula (o. } \\
\text { Korčula) } \\
\text { (Kalogjera, } \\
\text { Svoboda, } \\
\text { Josipović } \\
\text { 2008) } \\
\end{array}$ & \begin{tabular}{|l} 
Blato \\
(o. Korčula) \\
(Milat Pan- \\
ža 2015)
\end{tabular} \\
\hline $\begin{array}{l}\text { bôdul } \\
\text { bôdulka }\end{array}$ & bôdul & - & - & $\begin{array}{l}\text { bôdul } \\
\text { bôdulka }\end{array}$ & bôdul & - \\
\hline- & $\begin{array}{l}\text { Vläh/Vlãhinja } \\
\text { vläh } \\
\text { vlãhinja } \\
\text { vlahandïja } \\
\text { Vlãška }\end{array}$ & $\begin{array}{l}\text { Vläh } \\
\text { Vlãhińa } \\
\text { Vlãhińica } \\
\text { Vlâšse } \\
\text { Vlãšić } \\
\text { Vlašìna } \\
\text { Vlaharïja } \\
\text { Vlãško }\end{array}$ & $\begin{array}{l}\text { vläh } \\
\text { vlãhińa } \\
\text { vlahüja } \\
\text { Vlahïja } \\
\text { Vlãška }\end{array}$ & $\begin{array}{l}\text { vlâh } \\
\text { vlãhinja } \\
\text { Vlahadìja }\end{array}$ & $\begin{array}{l}\text { vläh (vläj) } \\
\text { vlähinja } \\
\text { (vläjna) } \\
\text { Vlahàrija }\end{array}$ & \begin{tabular}{|l} 
Vläh \\
Vlähinja \\
vlaharïja
\end{tabular} \\
\hline- & $\begin{array}{l}\text { škojôr } \\
\text { (škojõrka) } \\
\text { Škojôr } \\
\text { (Škojõrka) }\end{array}$ & $\begin{array}{l}\text { škojõr } \\
\text { škojõorka }\end{array}$ & \begin{tabular}{|l} 
škojor \\
škojõorka
\end{tabular} & $\begin{array}{l}\text { śkojôr } \\
\text { śkojôrka }\end{array}$ & $\begin{array}{l}\text { škojâr } \\
\text { (škojàrica) }\end{array}$ & $\begin{array}{l}\text { škojãr } \\
\text { škojarìca }\end{array}$ \\
\hline
\end{tabular}

i profesionalne) skupine, stanovnici zaleđa stanovnicima primorja” (Pavlović i Pavlović 2018: 566). Kao osobitost benkovačkoga rječnika treba istaknuti postojanje natuknice Vlak (također s uputnicom na Vlaji), koja se definira kao „stočar iz unutrašnjosti Balkana” (Pavlović i Pavlović 2018: 566). 
Naziv bodul uglavnom se navodi sa značenjem 'otočanin', no većina leksikografskih članaka donosi ogradu govornika od njegove upotrebe uz isticanje da stanovnike kojega otoka drugi tako zovu. Na primjer, u rječniku grada Hvara uz natuknicu bodul u značenju ‘otočanin’ navodi se rečenični primjer „Splićani za nos recedu da smo boduli, a mi recemo da smo iz otoka" (Benčić 2013: 106). U viškome rječniku također se navodi rečenični primjer u prvome licu množine: „Mi necemo nikad za sebe reci da smo boduli, naš je izraz škojor.” (Roki-Fortunato 1997: 34). Rječnik grada Korčule donosi „Korčulani ne kažu za sebe da su boduli." (Kalogjera, Svoboda i Josipović 2008: 30). To je u skladu sa zaključcima radova koji potvrđuju da naziv bodul nije u upotrebi na srednjodalmatinskim i južnodalmatinskim otocima, već da je riječ o novijoj pojavi, u posljednje vrijeme prisutnoj vjerojatno zbog češće pojave naziva bodul u elektroničkim i tiskanim medijima te osobito u popularnoj glazbi (Suić 1989: 22, Šimunović 2009: 27, Perinić Lewis 2017: 53).

Za razliku od bodula, prihvaćen je i dobro zastupljen naziv školjar. Na srednjodalmatinskim otocima mocijski par čine nazivi škojor/škojorka u značenju 'otočanin, stanovnik otoka' i 'otočanka, stanovnica otoka'. Najstereotipnija upotreba naziva škojor/škojorka je kod Bračana, koji tako zovu stanovnike i stanovnice otoka Hvara ${ }^{10}$ („Došla su dva škojora kupovat mihe po Broču.”) (Šimunović 2009: 927). Korčulanski rječnici uspostavljaju mocijski par škojar/škojarica.

Osim općenitog određenja ,stanovnik otoka ili škoja”, naziv škojor javlja se još u jednome značenju, kao naziv koji otočani upotrebljavaju za stanovnike manjih otočića u arhipelagu. Često se tada Škojor piše velikim početnim slovom. Primjerice, Hvarani Paklinske otoke, skupinu otoka pred gradom Hvarom, u svakodnevnome govoru nazivaju Škoji, a njihove stanovnike Škojori ${ }^{11}$ Stanovnici grada Korčule tako zovu stanovnike korčulanskih škoja, otočića Majsana i Vrnika. Pojavljuje se i naziv škojada za odlazak na izlet „u škoje” - korčulanske otočiće (Kalogjera, Svoboda i Josipović 2008: 347).

Bez obzira na upotrebu velikoga ili maloga početnog slova, naziv vlah/Vlah grupira se oko dvaju glavnih značenjskih polova. Prvo je i najčešće značenje

\footnotetext{
10 Uz razlikovno pisanje naziva $\breve{S} k o j$ velikim početnim slovom kad je riječ o Hvaru u rečeničnom primjeru: „Bi san prodovat końe po Škoju.” (Šimunović 2009: 927, s. v. škoj).

11 Potvrde se mogu naći u toponomastičkim radovima: „Pred Hvarom nalaze se Paklëni otöci ili Spalmadôri. Hvarani ih zovu śköji.” (Hraste 1956: 354) i „Hvarani Paklene otoke u svakodnevnom govoru nazivaju Šköji." (Kovačić 2008: 83).
} 
'stanovnik Dalmatinske zagore', i to je značenje potvrđeno u svim razmatranim otočnim rječnicima. Naziv vlah pisan malim početnim slovom odnosi se na 'najamnog, sezonskog radnika, najčešće iz Dalmatinske zagore’ (Benčić 2013: 492, Šimunović 2009: 1025, Roki-Fortunato 1997: 493). U Barbićevu rječniku Pitava i Zavale potvrđeno je isto značenje, ali je naziv pisan velikim početnim slovom (Barbić 2012: 353), dok se to značenje ne navodi u korčulanskim rječnicima. Pojavljuje se i treće, izrazito pogrdno značenje razmatranoga naziva - 'posprdni naziv za nekoga tko nije vičan moru i brodu’ (Benčić 2013: 492) i ‘čeljade koje se ne razumije ni u more ni u brod' (Barbić 2012: 353). Rječnik govora Blata donosi izdvojeno značenje naziva Vlah - 'neuglađen muškarac', dok za Vlahinju daje odrednicu 'priprosta žena' (Milat Panža 2015: 467).

U pogrdnome se značenju navode i nazivi vlahandija - 'skup vlaha, ljudi koji nisu vični moru' (Benčić 2013: 492), Vlašina - 'čeljade koje izgledom i ponašanjem djeluje kao Vlah' (Barbić 2012: 353), vlahuja - 'naziv za nekulturnu, neurednu ženu' (Šimunović 2009: 1026) i Vlahadija - 'pogrdno: svijet iz Zagore, ljudi s kopna odakle se ne vidi more' (Roki-Fortunato 1997: 571). Ovi nazivi svjedoče o negativnoj stereotipizaciji druge društvene skupine, koja je zbog brojnosti naziva otočanima sigurno bila bliska i vidljiva tijekom duljega razdoblja.

Prostor s kojega dolaze vlasi otočani također imenuju stereotipnim nazivima, umjesto da se koriste neutralnim geografskim imenom Dalmatinska zagora: Vlaška - 'mjesto odakle se ne vidi more, Dalmatinska zagora' (Benčić 2013: 492), Vlaško - 'Dalmatinska zagora' (Barbić 2012: 353), Vlahija i Vlaška - 'područje dalmatinske Zagore' (Šimunović 2009: 1025), Vlaharija - 'Vlaška (unutrašnjost, Dalmatinska zagora i sl.)' (Kalogjera, Svoboda i Josipović 2008: 391-392) i vlaharija - 'predio udaljen od mora, u unutrašnjosti' (Milat Panža 2015: 467). ${ }^{12}$

\footnotetext{
12 Trogirski i splitski kontrolni rječnici donose donekle očekivana značenja. U trogirskome natuknica škojar ima značenje 'otočanin, stanovnik otoka' (Geić i Slade Šilović 1994: 256), a Vlaj 'stanovnik Dalmatinske Zagore’ (Geić i Slade Šilović 1994: 290). Splitske potvrde obuhvaćaju sljedeća značenja: bodul 'onaj koji je s otoka, koji živi na otoku, otočanin' (Petrić 2008: 25), jednako kao i školjar 'onaj koji živi na otoku, koji je s otoka, otočanin' (Petrić 2008: 330). Širi raspon značenja, s nesporno stereotipnim elementima, očekivano nalazimo kod naziva vlaj (ž. vlajina) - 'onaj koji je iz dalmatinskog zaleđa, koji nije iz područja uz more' i u prenesenome, pejorativnome i deprecijativnome značenju 'onaj koji se teško unapređuje, koji ne prihvaća uobičajene norme ponašanja u gradu, koji se ponaša prostački, nepristojno, koji je nekulturan, primitivan, neuk, nazadan' (Petrić 2008: 393).
} 


\section{Zaključak}

U ovome radu istražili smo stereotipne nazive za otočane i stanovnike priobalnoga zaleđa, usmjerivši istraživački interes na nazive bodul, školjar i vlah u rječnicima hrvatskoga jezika. Sva tri naziva pojavljuju se i u općejezičnim rječnicima, koji donose neutralna značenja naziva i općeuporabni kontekst. Međutim, nijedan rječnik nije ostao samo na temeljnim značenjima istraživanih naziva, već svi u određenome opsegu navode i regionalna, razgovorna, pejorativna i derogativna značenja. Naziv bodul ima najčešće dvije značenjske odrednice, osim općega značenja 'otočanina' u rječnicima je istaknuto njegovo regionalno značenje vezano uz prostor Kvarnera i Hrvatskoga primorja, gdje se upotrebljava za stanovnike otoka Krka. Naziv školjar potvrđen je u dvama općejezičnim rječnicima, i to u općenitome značenju 'stanovnik otoka (školja)'. Najveći je broj inačica zapisa naziva $v l a h$, ujedno s najvećim brojem onih koje su obilježene kao regionalne, pa i pejorativne i derogativne, a čije definicije sadržavaju stereotipne predodžbe o drugoj i drukčijoj društvenoj skupini te su bliže komunikacijskim zahtjevima pojedine govorne zajednice nego općejezičnomu rječniku.

Polazna pretpostavka o tome da ćemo u dijalektnim rječnicima hrvatskih govora pronaći obilje primjera stereotipnih predodžba pri uspostavi definicija i u navođenju kontekstnih primjera pokazala se točnom. S obzirom na rječničke potvrde naziva bodul, školjar i vlah, utvrdili smo da su razmatrani nazivi rasprostranjeni duž jadranskoga otočja, no nejednoliko. Na Kvarneru i dijelu sjevernodalmatinskih otoka prisutniji je naziv bodul, a na srednjodalmatinskim i južnodalmatinskim otocima školjar, no na srednjodalmatinskim i južnodalmatinskim otocima stanovnici se ograđuju od naziva bodul navodeći da ih tako nazivaju drugi. Bodul je na Kvarneru prihvaćen kao naziv za otočanina, osobito na otoku $\mathrm{Krku}$, koji im dodjeljuju stanovnici i primorskih i kontinentalnih područja. Naziv je u povijesti bio pejorativan, no danas ga prihvaćaju i sami stanovnici Krka, dok su stanovnicima susjednoga priobalja jedini boduli Krčani i nitko drugi. Osim osnovnoga značenja 'Krčanin' pejorativno značenje (‘škrtost') zabilježeno je samo u jednome analiziranom rječniku primorskoga područja - u grobničkome rječniku. Naziv školjar potvrđen je u velikome broju inačica i značenja na srednjodalmatinskim i južnodalmatinskim otocima, a otočani ga, za razliku od naziv bodul, prihvaćaju. Zamjetno je da se naziv školjar upotrebljava u me- 
đuotočnim stereotipizacijama, pa se neki otočani koriste njime za imenovanje stanovnika manjih otoka u pojedinome arhipelagu ili za stanovnike susjednih otoka (Bračani za otok Hvar i njegove stanovnike). Sva tri naziva, bodul, školjar i vlah, u ovisnosti o geografskome smještaju, stereotipiziraju različite skupine, ali katkad se samoimenovanja odlikuju i neutralnim značenjima. Posljednja tvrda odnosi se na nazive bodul i školjar, ali nikada za naziv vlah. Naziv vlah u rječnicima je najplodniji naziv za određenu skupinu, potvrđen je bez iznimke u gotovo svim istraživanim otočnim rječnicima osim kvarnerskih. U njegovim su određenjima stereotipna obilježja najzastupljenija te često obuhvaćaju više stereotipnih kategorija.

Kopneni pogled često generalizira otoke, primjerice, različite otoke srednjodalmatinskoga otočja (Brač, Hvar i Vis) Splićani nazivaju prvi, drugi i treći Brač (Šimunović 2009: 27). S druge strane, otočno stereotipiziranje kopnenoga stanovništva pokazalo je puno veću kreativnost u stvaranju stereotipnih naziva, njihovih inačica i definicija. Zanimljivi su rezultati istraživanja o tome tko je kojemu otoku vlah, odnosno iz kojega točno dijela kopna i/ili regije dolazi. Budući da su hrvatski otoci priobalni i orijentirani na najbliže kopno te povezani s najbližim primorskim gradovima, to je vidljivo i u određivanju geografskoga prostora iz kojega dolaze vlasi. Na otoku Pagu vidljiva je različitost s obzirom na pojedina otočna naselja. Za stanovnike grada Paga i Novalje vlasi dolaze iz podvelebitskoga područja i zaleđa. Stanovnici paškoga mjesta Kolana vlasima pak nazivaju Ličane i Ličanke, dok u rječniku Povljane nalazimo potvrdu da vlaj i vlajina (jedan od rijetkih otočnih rječnika s tom inačicom, odnosno sa završnim j) dolaze iz Bukovice u Dalmatinskoj zagori, a vlasima (u množini) smatraju se stanovnici Ravnih kotara. Naziv vlaharija (pisan ili malim ili velikim početnim slovom) pojavljuje se u svim paškim rječnici te se određuje kao naziv za neodređeni prostor na kopnu, udaljen od mora, ili preko Velebita/planine. U urbanim se otočnim centrima Pagu i Novalji vlaharija koristi i kao zbirna imenica za stanovništvo iz zaleđa te, u pejorativnome značenju, za ljude koji se ponašaju necivilizirano.

U zaleđu Zadra (Ravni kotari i Bukovica) svoje vlahe nalaze i stanovnici sjevernodalmatinskih otoka Ošljaka, Vrgade, Murtera, mjesta Sali na Dugome otoku i Kukljice na Ugljanu. Naziv Vlahorija poznat je na svim otocima, osim 
Ista, a označuje neodređeno područje iznad mora. Na otoku Rivnju taj se naziv koristi i za stanovnike i za prostor.

$\mathrm{Na}$ srednjodalmatinskim i južnodalmatinskim otocima Hvaru, Braču, Visu i Korčuli naziv vlah upotrebljava se za stanovnika Dalmatinske zagore, uz gotovo obavezan dodatak ,odakle se ne vidi more”. Za prostor Zagore, gdje žive vlasi, koriste se i nazivi Vlaška, Vlaško, Vlahija i Vlaharija (dvojni naziv kojim se označuju ljudi i prostor), što zapravo podsjeća na naziv Bodulija koji označuje područje otoka Krka. Drugo je značenje naziva vlah sezonski ili najamni radnik, nadničar iz Zagore koji je dolazio na otok u sezonske poslove, što je dokaz čestoga susretanja i komunikacije otočana sa skupinama koje stereotipiziraju. Inačica vlaj nije potvrđena u otočnim rječnicima (osim u rječniku Povljane na Pagu te u rječniku grada Korčule), ali je zato nalazimo u rječnicima govora Splita i Trogira, što potvrđuje tvrdnju Ivana Botice da je ta inačica naziva karakteristična za splitsko područje, ali ne i za dalmatinske otoke. Na dalmatinskim se otocima pojavljuju zbirne imenice (vlahandija, vlahadija, Vlašad) s trećim, pogrdnim značenjem o ljudima koji nisu vični moru i brodu te mnogo stereotipnijim određenjem necivilizirane i neuljudne osobe.

Na primjeru naziva za ženske osobe (bodulka, bodulica, škojorka, škojarica, vlahinja, vlajina) često je vidljiva i rodna stereotipizacija. U nazivu vlahinja i drugim inačicama vidljiva je dvostruka stereotipizacija - s obzirom na društveni status i s obzirom na rodnu pripadnost. Veći je broj pejorativnih značenja nego kod ostalih naziva za žensku osobu, primjerice u blatskome rječniku Vlahinja je priprosta žena, a vlahuja u bračkome rječniku označuje nekulturnu i neurednu ženu. Osim toga, u definicijama naziva vlahinja zamjetno se češće navode izreke koje počivaju na stereotipnim određenjima. Primjeri su vezani uz ženidbu s vlahinjom, pri čemu se naglašava da kad muškarac na otoku nije mogao oženiti otočanku, morao je ili je barem mogao oženiti vlahinju (primjeri u paškim rječnicima).

Svakako valja istaknuti da otočani imaju vlahe i na svojim otocima, upotrebljavajući taj naziv u unutarotočnim stereotipizacijama za doseljenike koji su nastanili ili čak osnovali neka novija otočna naselja (primjerice Sućuraj na Hvaru, Sumartin na Braču, Račišće na Korčuli). Iako su oni otočani već nekoliko stoljeća, obilježeni su i stereotipizirani kao otočni drugi. Često ih danas nazivaju ,otočnim Vlasima” te svojim, otočnim gorštacima (Perinić Lewis 2017: 151-158). 
Istraživani nazivi bodul, školjar i vlah imaju stereotipne značajke te unatoč činjenici da su neki vrlo stari, njihova današnja upotreba dokaz je trajnosti te primjene i u suvremenoj komunikaciji među društvenim skupinama i unutar njih. Oni su elementi identifikacijskih procesa konstruiranja i održavanja predodžba o vlastitoj i drugoj skupini.

\section{Izvori (rječnici)}

Anić, Vladimir. 2005. Veliki rječnik hrvatskoga jezika. Novi Liber. Zagreb.

Barbić, Ante. 2012. Rječnik Pitava i Zavale. Institut za hrvatski jezik i jezikoslovlje. Zagreb.

BenČić, Radoslav. 2013. Rječnik govora grada Hvara. Fõrske rîci i štörije. Muzej hvarske baštine. Hvar.

Bralić, Ivanka. 2014. Čakavske besede moje $i$ sih mojih z Šmrike i Kraljevice. Udruga u kulturi „Stol”. Kraljevica - Rijeka.

Galović, FiLIP. 2019. Govori otoka Šolte. Općina Šolta - Hrvatsko katoličko sveučilište. Zagreb.

GeIć, DušKo; Slade ŠIlović, MiRKo. 1994. Rječnik trogirskog cakavskog govora. Muzej grada Trogira. Trogir.

IVANČIĆ DusPer, ĐurĐiCA; BAŠIĆ, MaRTINA. 2013. Rječnik crikveničkoga govora. Centar za kulturu Dr. Ivan Kostrenčić. Crikvenica.

JojIĆ, Ljiljana (gl. ur.). 2015. Veliki rječnik hrvatskoga standardnog jezika. Školska knjiga. Zagreb.

Juraga, Edo. 2010. Rječnik govora otoka Murtera. Ogranak Matice hrvatske Murter Županijski muzej Šibenik. Murter - Šibenik.

JURIŠIĆ, BLAž. 1973. Rječnik govora otoka Vrgade uspoređen s nekim čakavskim i zapadnoštokavskim govorima. II. dio (rječnik). Jugoslavenska akademija znanosti i umjetnosti. Zagreb.

Kalogjera, Damir; Svoboda, Mirjana; Josipović, Višnja. 2008. Rječnik govora grada Korčule. Novi Liber. Zagreb.

Klaić, Bratoljub. 2012. Novi rječnik stranih riječi. Školska knjiga. Zagreb.

Kustić, Nikola. 2002. Cakavski govor grada Paga. Društvo Pažana i prijatelja grada Paga. Zagreb.

LukeŽıć, Iva; Zubčıć, SANJA. 2007. Grobnički govor XX. stoljeća (gramatika i rječnik). Katedra Čakavskog sabora Grobnišćine. Rijeka. 
Mahulja, Ivan. 2006. Rječnik omišaljskoga govora. Riječki nakladni zavod - Općina Omišalj. Rijeka - Omišalj.

Maričić KuklJIČAnin, Tomislav. 2000. Rječnik govora mjesta Kukljica na otoku Uglja$n u$. Matica hrvatska Zadar. Zadar.

Milat PanžA, Petar. 2015. Rječnik govora Blata na Korčuli. Institut za hrvatski jezik i jezikoslovlje. Zagreb.

OšTARIĆ, Ivo. 2005. Rječnik kolanjskoga govora ili Ričnik mista Kolana na otoku Pagu. Matica hrvatska Zadar. Zadar.

Pavlović, Alouz; PAvlović, EduARd. 2018. Rječnik novoštokavske ikavice benkovačkoga kraja. Ogranak Matice hrvatske u Zadru. Zadar.

Petrić, ŽeljKo. 2008. Rječnik starih splitskih riječi i izraza. Naklada Bošković. Split.

Piasevoli, AnKiCA. 1993. Rječnik govora mjesta Sali na Dugom otoku oliti Libar saljski besid. Matica hrvatska Ogranak Zadar. Zadar.

RADUlić, LADISLAV. 2002. Rječnik rivanjskog govora. Matica hrvatska Zadar. Zadar.

Roki-Fortunato, Andro. 1997. Lîbar vĩškiga jazíka. Libar Publishing. Toronto.

SmolJan, AnTE. 2015. Rječnik govora otoka Ista. Matica hrvatska Ogranak Zadar. Zadar.

Sкок, Petar. 1971. Etimologijski rječnik hrvatskoga ili srpskoga jezika. Knjiga I. A - J. Jugoslavenska akademija znanosti i umjetnosti. Zagreb.

SKOK, Petar. 1973. Etimologijski rječnik hrvatskoga ili srpskoga jezika. Knjiga III. poni - Ž. Jugoslavenska akademija znanosti i umjetnosti. Zagreb.

ŠIMUNIĆ, BožIDAR. 2013. Rječnik bibinjskoga govora. Matica hrvatska. Zadar.

Šimunović, Petar. 2009. Rječnik bračkih čakavskih govora. Golden marketing - Tehnička knjiga. Zagreb.

ŠOnJe, Jure (ur.) 2000. Rječnik hrvatskoga jezika. Leksikografski zavod Miroslav Krle$\check{z} a-\breve{S} k o l s k a$ knjiga. Zagreb.

Tičıć, AnTe. 2004. Rječnik govora mjesta Povljane na otoku Pagu. Lîbar povljânski besîd. Matica hrvatska Zadar. Zadar.

TurČIĆ, Branko. 2002. Sedmoškojani. Prvi čokavski rječnik. Adamić. Rijeka.

VALČić, Ante Toni. 2012. Rječnik govora otoka Ošljaka. Matica hrvatska Ogranak Zadar. Zadar.

VelČIĆ, Nikola, 2003. Besedar Bejske Tramuntane. Adamić. Mali Lošinj - Beli - Rijeka.

VRanić, Silvana; Oštarić, Ivo. 2016. Rječnik govora Novalje na otoku Pagu. Ogranak Matice hrvatske u Novalji - Filozofski fakultet Sveučilišta u Rijeci. Novalja - Rijeka. 


\section{Literatura}

Berger, Peter L.; Luckmann, Thomas. 1992. Socijalna konstrukcija zbilje: rasprava o sociologiji znanja. Naprijed. Zagreb.

Bнавна, Номі. 1994. The location of culture. Routledge. London - New York.

Botica, Ivan. 2005. Prilog istraživanju najstarijega spomena vlaškog imena u hrvatskoj historiografiji. Radovi-Zavod za hrvatsku povijest 37. 35-46.

Botica, Ivan. 2007. Vlah i vlah - nekoć i danas. Jezik i identiteti. Ur. Granić, Jagoda. Hrvatsko društvo za primijenjenu lingvistiku. Zagreb - Split. 61-69.

Bourdieu, Pierre. 1991. Language and Symbolic Power. Polity Press. Cambridge.

Bozanić, Anton. 2019. Naziv „boduli” - podrijetlo, značenje i primjereno sadašnje služenje tim nazivom. Krčki zbornik 75. 145-157.

Braudel, Ferdinand. 1997. Sredozemlje i sredozemni svijet u doba Filipa II. Svezak I. Antibarbarus. Zagreb.

ČAPO ŽMEGAČ, JASNA. 1997. Objektivni i subjektivni čimbenici identifikacije sa zajednicom, Etnološka tribina 20. 69-82.

ČAPO ŽMEGAČ, JASNA. 2002. Srijemski Hrvati. Etnološka studija migracije, identifikacije i interakcije. Durieux. Zagreb.

DžAмво, Jozo. 1999. Maledicta Ethnica. O nacionalnim stereotipima i verbalnoj agresiji. Zbornik u čast dr. Ignacija Gavrana. Ur. Pranjković, Ivo; Jeličić, Slavko. Udruga đaka franjevačke klasične gimnazije Visoko. Zagreb.

FEHÉr, IsTVÁn. 2006. Ni neutralnost ni poricanje sebe, nego otvorenost. Kulturni stereotipi. Koncepti identiteta u srednjoeuropskim književnostima. Ur. Oraić Tolić, Dubravka; Kulcsár Szabó, Erno. FF press. Filozofski fakultet, Zavod za znanost o književnosti. Zagreb. 59-70.

Hall, Stuart. 1997. The spectacle of 'Other'. Representation. Cultural representations and signifying practices. Ur. Hall, Stuart. Sage Open University - London. 223-291.

HefFer, Hrvoja. 2007. Biološka i društvena kategorija roda u rodnoj teoriji i rodna teorija stereotipa. Rasprave Instituta za hrvatski jezik i jezikoslovlje 33. 165-175.

Hraste, Mate. 1956. Antroponimija i toponimija općine hvarske. Hrvatski dijalektološki zbornik 1. 331-385.

Kolbas, Irena. 2013. Vic o plavuši: stereotipi u kojima živimo: katalog izložbe / Blonde joke: stereotypes we live by: exhibition catalogue. Etnografski muzej. Zagreb. 9-67.

Kovačec, August. 2016. Podrijetlo i razvitak naziva Vlah, Vlasi (vlah, vlasi), vlaški. Hrvatska revija 3/XVI. 3-9.

KovAčı́́, JošKo. 2008. Prilozi za Martina Benetovića - Benkovića. Čakavska rič XXXVI/1-2. 159-188. 
Lippmann, Walter. 1995. Javno mnijenje. Naprijed. Zagreb.

Lovrić, Ivan. 1948. [1776.] Bilješke o Putu po Dalmaciji opata Alberta Fortisa i Život Stanislava Sočivice. Preveo Mihovil Kombol. Izdavački zavod Jugoslavenske akademije. Zagreb.

Matvejević, Predrag. 2006. Mediteranski brevijar. VBZ. Zagreb.

Mirdita, Zef. 2004. Vlasi u historiografiji. Hrvatski institut za povijest. Zagreb.

Mirošević, Lena; Vukosav, Branimir. 2010. Prostorni identiteti otoka Paga i južnoga podvelebitskog primorja. Geoadria 15/1. 81-108.

NovaK, Grga. 1959. Dalmacija godine 1775/6. gledana očima jednog suvremenika. Starine JAZU 49. 5-80.

Perinić Lewis, Ana. 2017. Otoci otoka Hvara. Pluralizam lokalnih otočnih identifikacija. Hrvatska sveučilišna nastava. Zagreb.

Pickering, Michael. 2001. Stereotyping: The politics of representation. Palgrave. New York.

Rubić, Ivo. 1952. Naši otoci na Jadranu. Izdanje Odbora za proslavu desetgodišnjice Mornarice. Split.

STRAŽIČIĆ, NiKOLA. 1987. Prirodno-geografske značajke kao poticajni i ograničavajući faktori razvoja Jadranskih otoka, Pomorski zbornik 25/1. 39-55.

Suić, Mate. 1989. Bodul - prilog antroponimiji i toponimiji istočnojadranskog područja. Onomastica Jugoslavica 13. 21-27.

\section{Stereotypical Terms for the Islanders and the Inhabitants of the Coast and Hinterland in Dictionaries of the Croatian Language}

\section{Abstract}

In this paper the authors analyse stereotypical terms bodul, školjar and vlah, and consider the meanings and contexts in which stereotypical features are attributed to them. The etymologies of these terms have been presented and discussed. Meanings, usage contexts and terminological inconsistencies have been analysed in selected dictionaries of the Croatian standard language and dialect dictionaries. The distribution of these terms along the Adriatic has been presented and conclusions offered as to whether this phenomenon should be considered as a regional or supraregional one.

Ključne riječi: stereotip, stereotipni naziv, bodul, školjar, vlah, rječnici hrvatskoga jezika Keywords: stereotype, stereotypical term, bodul, školjar, vlah, Croatian language dictionaries 